\title{
OPEN Author Correction: Comparison of pressure- and volume-controlled ventilation during laparoscopic colectomy in patients with colorectal cancer
}

\author{
Sangbong Choi, So Young Yang, Geun Joo Choi, Beom Gyu Kim \& Hyun Kang
}

Correction to: Scientific Reports https://doi.org/10.1038/s41598-019-53503-9, published online 18 November 2019

The original version of this Article contained an error in Affiliation 2, which was incorrectly given as 'Anesthesiology and Pain Medicine, Seoul, Korea'. The correct affiliation is listed below:

Anesthesiology and Pain Medicine, Chung-Ang University College of Medicine, Seoul, Korea

This error has now been corrected in the HTML and PDF versions of the Article.

(1) Open Access This article is licensed under a Creative Commons Attribution 4.0 International License, which permits use, sharing, adaptation, distribution and reproduction in any medium or format, as long as you give appropriate credit to the original author(s) and the source, provide a link to the Creative Commons license, and indicate if changes were made. The images or other third party material in this article are included in the article's Creative Commons license, unless indicated otherwise in a credit line to the material. If material is not included in the article's Creative Commons license and your intended use is not permitted by statutory regulation or exceeds the permitted use, you will need to obtain permission directly from the copyright holder. To view a copy of this license, visit http://creativecommons.org/licenses/by/4.0/.

(C) The Author(s) 2020 